\title{
Regulation of Glucose-6-Phosphate Dehydrogenase in Brevibacterium flavum
}

\author{
Shin-ichi Sugimoto and Isamu SHIIO \\ Central Research Laboratories, Ajinomoto Co., Inc., \\ Kawasaki-ku, Kawasaki, Kanagawa 210, Japan
}

Received June 20, 1986

\begin{abstract}
NADP-Specific G6P dehydrogenase was partially purified from Brevibacterium flavum. Its activity, with an optimum $\mathrm{pH}$ of 7.5 , was stabilized by $\mathrm{KCl}$ or $\mathrm{Mg}^{2+}$ and inhibited by diamide, a sulfhydrylireagent. It was also inhibited by oxaloacetate, FBP, PRPP, acetyl-CoA, Ru5P, xylulose 5phosphate and NADPH. Among them, oxaloacetate showed the strongest inhibition. The concentration of oxaloacetate giving $50 \%$ inhibition was $0.09 \mathrm{~mm}$. The inhibitions by oxaloacetate, FBP, PRPP, and NADPH were non-competitive, mixed, and competitive for both the substrates, respectively. Oxaloacetate in combination with FBP, PRPP, or Ru5P inhibited the activity cumulatively. The sensitivities to the oxaloacetate, FBP, and PRPP inhibitions were lost on ammonium sulfate treatment, whereas that to NADPH inhibition was not affected at all. The inhibition by oxaloacetate was specific to glutamate-producing bacteria belonging to the genera, Brevibacterium and Corynebacterium, in contrast to those by FBP and PRPP, which were found in almost all bacteria tested. G6P dehydrogenase in B. flavum was induced by glucose when it was cultured on acetate, succinate, or glutamate.
\end{abstract}

The contribution of the pentose phosphate pathway to glucose metabolism in Brevibacterium flavum has been indicated by the metabolism of various ${ }^{14} \mathrm{C}$-labeled glucoses ${ }^{11}$ and supported by the presence of G6P dehydrogenase activity in the cell-free extract. ${ }^{2)}$ However, its contribution to pyruvate formation from glucose was estimated to be only about $10 \%{ }^{\circ}{ }^{1)}$ Furthermore, glucose phosphate isomerase-deficient mutants of B. flavum did not grow on glucose but did on gluconate. ${ }^{3)}$ These results suggest that in B. flavum the pentose phosphate pathway is not a main route for glucose metabolism, but that it operates to supply erythrose 4-phosphate and PRPP, precursors for aromatic amino acid biosynthesis. Since some mutants of B. flavum have been bred as aromatic amino acidproducing strains, ${ }^{4)}$ it is interesting to elucidate the regulatory mechanisms for the biosynthesis of these precursors via the pentose phosphate pathway.

This paper deals with the control of the activity and synthesis of G6P dehydrogenase, the first step enzyme of the pathway in $B$. flavum.

\section{MATERIALS AND METHODS}

Organisms. Brevibacterium flavum No. 2247 (ATCC 14067) was used. In addition, the organisms listed in Table $\mathrm{V}$ were used for comparison with $B$. falvum as to the regulation of G6P dehydrogenase.

Media. A complex medium, Medium $7,{ }^{5)}$ and a minimal medium, Medium 13, ${ }^{5}$ were used. Medium 40, which was a modification of Medium 29, ${ }^{6}$ was composed of $50 \mathrm{~g}$ of monosodium glutamate or $20 \mathrm{~g}$ of an organic acid plus $15 \mathrm{~g}$ of $\left(\mathrm{NH}_{4}\right)_{2} \mathrm{SO}_{4}, 5 \mathrm{~g}$ of $\mathrm{KH}_{2} \mathrm{PO}_{4}, 1.2 \mathrm{~g}$ of $\mathrm{MgSO}_{4} \cdot 7 \mathrm{H}_{2} \mathrm{O}$, $100 \mathrm{mg}$ of $\mathrm{FeSO}_{4} \cdot 7 \mathrm{H}_{2} \mathrm{O}, 8 \mathrm{mg}$ of $\mathrm{MnSO}_{4} \cdot 4 \mathrm{H}_{2} \mathrm{O}, 100 \mu \mathrm{g}$ of thiamine $\mathrm{HCl}, 500 \mu \mathrm{g}$ of $d$-biotin, and $3 \mathrm{~g}$ of yeast extract (Daigo Eiyo) in a total volume of 1 liter. The $\mathrm{pH}$ was adjusted to 7.0 with $\mathrm{NaOH}$ and then the medium was sterilized at $115^{\circ} \mathrm{C}$ for $10 \mathrm{~min}$.

Abbreviations: G6P, glucose 6-phosphate; TES, $N$-tris-(hydroxymethyl)methyl-2-aminoethane sulfonic acid; PRPP, phosphoribosyl pyrophosphate; FBP, fructose 1,6-bisphosphate; Ru5P, ribulose 5-phosphate; acetyl-CoA, acetyl coenzyme A. 
Chemicals. G6P, NADP and NADPH were purchased from Boehringer Mannheim. Oxaloacetate and DEAEcellulose (DE-52) were from ICN Pharmaceuticals and Whatman, respectively. Other chemicals were purchased from Sigma Chemical Co. and Boehringer Mannheim.

Enzyme preparation. Cells of B. flavum No. 2247 cultured in $500-\mathrm{ml}$ flasks containing $50 \mathrm{ml}$ of Medium 13 at $30^{\circ} \mathrm{C}$ for $24 \mathrm{hr}$ were harvested, washed twice with $0.2 \%$ $\mathrm{KCl}$ and then suspended in $0.1 \mathrm{M}$ Tris-buffer, $\mathrm{pH} 7.5$, containing $10 \mathrm{~mm} \mathrm{MgCl}_{2}$. Then, the cells were sonically disrupted at $10 \mathrm{kc}$ for $20 \mathrm{~min}$. The cell-free extract obtained by centrifugation at $32,000 \times g$ for $30 \mathrm{~min}$ (Fraction I) was placed on a DEAE-cellulose column $(2.5 \times 22 \mathrm{~cm})$ equilibrated with $0.05 \mathrm{M}$ Tris- $\mathrm{HCl}$ buffer, $\mathrm{pH} 7.5$, containing $30 \mathrm{~mm} \mathrm{MgCl}_{2}$. The column was washed with $100 \mathrm{ml}$ of the same buffer. G6P dehydrogenase was eluted with a $\mathrm{KCl}$ concentration gradient consisting $500 \mathrm{ml}$ of the same buffer and the latter containing $0.4 \mathrm{M} \mathrm{KCl}$. In order to stabilize the enzyme, $\mathrm{KCl}$ solution was added to the test tubes before the elution, to give a final concentration of $0.5 \mathrm{M}$. Fractions of $8 \mathrm{ml}$ were collected. The fractions containing G6P dehydrogenase activity were pooled, concentrated with an ultrafiltration apparatus (Amicon PM10) and then used as the enzyme preparation (Fraction II). Since the enzyme preparation contained small amounts of the activities of aldolase, glucose phosphate isomerase, phosphoglucomutase, and 6-phosphogluconate dehydrogenase, the effects of fructose 6-phosphate, FBP, glyceraldehyde 3-phosphate, dihydroxyacetone phosphate and glucose 1-phosphate on the activity, as shown in Table II, were determined after the contaminating enzymes had been removed from the preparation by rechromatography under the same conditions as for the first chromatography (Fraction III).

Assay method. G6P dehydrogenase was assayed by measuring the increase in absorbancy at $340 \mathrm{~nm}$ of the reaction product, NADPH. The standard reaction mixture contained $0.05 \mathrm{M}$ Tris- $\mathrm{HCl}$ buffer, $\mathrm{pH} 7.5,10 \mathrm{mM} \mathrm{MgCl}_{2}$, $2 \mathrm{~mm}$ G6P, $0.5 \mathrm{~mm}$ NADP and the enzyme in a total volume of $0.5 \mathrm{ml}$. One unit of the activity was defined as that catalyzing the formation of $1 \mathrm{nmol}$ of $\mathrm{NADPH}$ per $\min$.

Protein was determined by the method of Lowry et al. ${ }^{7)}$

\section{RESULTS}

\section{General properties}

As shown in Table I, when G6P dehydrogenase in cell-free extracts was transferred into Tris- $\mathrm{HCl}$ buffer, $\mathrm{pH} 7.5$, by gel filtration, it lost its activity completely, but was stabilized by the addition of $0.5 \mathrm{M} \mathrm{KCl}$ or $10 \mathrm{mM} \mathrm{MgCl}_{2}$. G6P and NADP, the substrates, and dithio-
Table I. Stability of Glucose-6-Phosphate DEHYDROGENASE

The cell-free extract (Fraction I) was passed through a Sephadex G-25 column $(1.5 \times 5 \mathrm{~cm})$ equilibrated with $0.05 \mathrm{~m}$ Tris- $\mathrm{HCl}$ buffer, $\mathrm{pH} 7.5$, containing the additions indicated in the table. Then, the activity was measured under the standard assay conditions. The specific activities relative to that of the cell-free extract are listed in the table. The specific activity of the cell-free extract was 85 units/mg protein.

\begin{tabular}{lc}
\hline \multicolumn{1}{c}{ Addition to buffer } & Activity $(\%)$ \\
\hline None & 0 \\
$0.5 \mathrm{M} \mathrm{KCl}$ & 130 \\
$10 \mathrm{mM} \mathrm{MgCl}$ & 118 \\
$1 \mathrm{mM} \mathrm{Dithiothreitol}$ & 25 \\
$1 \mathrm{mM} \mathrm{G6P}$ & 15 \\
$0.1 \mathrm{~mm}$ NADP & 21 \\
\hline
\end{tabular}

threitol showed slight stabilizing effects. Then, the enzyme was partially purified in the presence of $\mathrm{KCl}$ and $\mathrm{Mg}^{2+}$ from the cell-free extract by DEAE-cellulose column chromatography. It was eluted from the column with $0.12 \mathrm{M} \mathrm{KCl}$ and purified about 3-fold. When further purified by column chromatography on Sephadex G-200 or hydroxyapatite in the presence of $\mathrm{KCl}$ and $\mathrm{Mg}^{2+}$ but in the absence of an $\mathrm{SH}$ group stabilizing agent, it was inactivated or desensitized to the regulation, respectively. Therefore, the fraction obtained on DEAE-cellulose column chromatography was used as the enzyme preparation.

The enzyme reaction completely depended on the substrates, G6P and NADP, and did not proceed with NAD at all, similarly to the previous results obtained using cell-free extracts. ${ }^{2}$ The enzyme required $\mathrm{Mg}^{2+}$ for its activity and showed the maximum activity at more than $6 \mathrm{~mm}$. The activity without $\mathrm{Mg}^{2+}$ was only $1 \%$ of that with $10 \mathrm{~mm} \mathrm{Mg}^{2+} \cdot \mathrm{Mn}^{2+}$ also developed the enzyme activity, which was, however, only $77 \%$ of that with $10 \mathrm{~mm} \mathrm{Mg}^{2+}$ at the optimum concentration of $3 \mathrm{~mm}$.

The optimum $\mathrm{pH}$ of the reaction was 7.5 with both TES-NaOH and Tris- $\mathrm{HCl}$ buffers (Fig. 1).

When the enzyme reaction was started after preincubation of the enzyme with diamide, a 


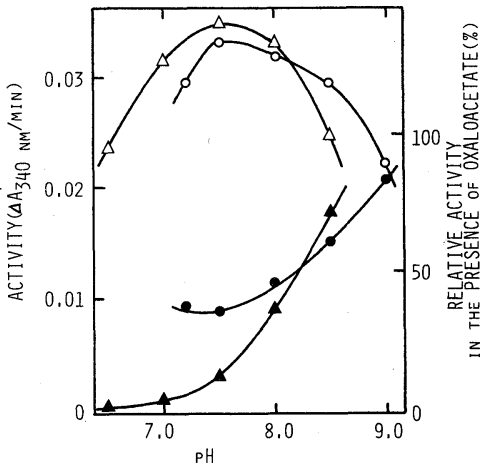

FIG. 1. Effects of $\mathrm{pH}$ Glucose-6-phosphate Dehydrogenase Activity and on the Inhibition by Oxaloacetate.

The reactions were carried out using Fraction II in the presence and absence of $1 \mathrm{~mm}$ oxaloacetate under the standard assay conditions except that buffers of various pHs, $0.15 \mathrm{~mm}$ G6P and $0.15 \mathrm{~mm}$ NADP were used. and $-\mathrm{O}-$, Tris- $\mathrm{HCl}$ buffer; $-\mathbf{\Delta}-$, and $-\triangle-$, TES$\mathrm{NaOH}$ buffer. $-\mathrm{O}-$ and $-\triangle-$, enzyme activity; - - and - $\mathbf{-}-$, relative activity in the presence of $1 \mathrm{~mm}$ oxaloacetate. sulfhydryl reagent, for $90 \mathrm{sec}$, the activity decreased to $0.8 \%$ of that without diamide but was completely recovered on further incubation with $30 \mathrm{~mm}$ dithiothreitol. This indicates that a sulfhydryl group is involved in the active site of the enzyme.

Figure 2 shows double reciprocal plots of the reaction rate against the substrate concentrations. Plots against both the substrates gave straight lines that intersected at a point, indicating that the reaction mechanism was sequential. The $K m$ s for G6P and NADP were calculated from the plots of the intercepts at the vertical lines against the reciprocals of the second substrate concentrations to be 0.14 and $0.024 \mathrm{~mm}$, respectively.

\section{Regulation of glucose-6-phosphate dehydro- genase activity \\ The effects of various metabolites on the}

Table II. EfFects of Metabolites on Glucose-6-Phosphate Dehydrogenase

The activity was measured using Fraction II (327 units/mg protein) in the presence and absence of the additions under the standard assay conditions except that the concentrations of G6P and NADP were $0.15 \mathrm{~mm}$. The relative activities in the presence of fructose 6-phosphate, FBP, glyceraldehyde 3-phosphate, dihydroxyacetone phosphate and glucose 1-phosphate were determined using the rechromatographed enzyme preparation (Fraction III, 626 units/mg protein), as described in MATERIALS AND METHODS.

\begin{tabular}{|c|c|c|c|}
\hline $\begin{array}{l}\text { Addition } \\
(1 \mathrm{~mm})\end{array}$ & $\begin{array}{c}\text { Relative activity } \\
((\%)\end{array}$ & $\begin{array}{l}\text { Addition } \\
(1 \mathrm{~mm})\end{array}$ & $\begin{array}{l}\text { Relative activity } \\
(\%)\end{array}$ \\
\hline None & 100 & Fructose-1P & 106 \\
\hline 6-Phosphogluconate & 102 & Citrate & 94 \\
\hline Ru5P & 73 & 2-Oxoglutarate & 101 \\
\hline Xylulose-5P & 74 & Succinate & 97 \\
\hline Ribose-5P & 80 & Fumarate & 97 \\
\hline PRPP & 64 & Malate & 97 \\
\hline Sedoheptulose-7P & 103 & Oxaloacetate & 33 \\
\hline Erythrose-4P & 90 & L-Glutamate & 97 \\
\hline Fructose-6P & 94 & L-Aspartate & 100 \\
\hline FBP & 60 & ATP & 96 \\
\hline Glyceraldehyde-3P & 82 & ADP & 90 \\
\hline Dihydroxyacetone-P & 93 & AMP & 94 \\
\hline 3-Phosphoglycerate & 95 & GMP & 90 \\
\hline 2-Phosphoglycerate & 93 & L-Tryptophan & 99 \\
\hline Phosphoenolpyruvate & 90 & L-Phenylalanine & 96 \\
\hline Pyruvate & 98 & L-Tyrosine & 92 \\
\hline Acetyl-CoA & 74 & L-Histidine & 99 \\
\hline Glucose-1P & 100 & & \\
\hline Glucose 1,6-bisP & 74 & $\mathrm{NADPH}^{a}$ & 48 \\
\hline Fructose 2,6-bisP & 73 & $\mathrm{NADH}^{b}$ & 111 \\
\hline
\end{tabular}

a $\quad 0.1 \mathrm{mM}$

b $\quad 0.15 \mathrm{~mm}$. Abbreviation: $\mathrm{P}$, phosphate. 


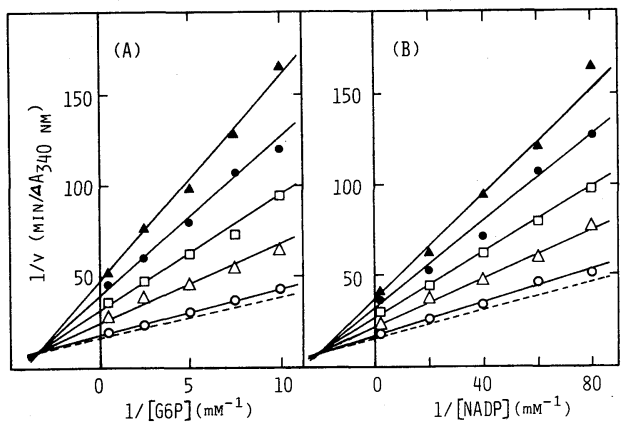

FIG. 2. Double Reciprocal Plots of the Glucose-6phosphate Dehydrogenase Reaction Rate against the Substrate Concentration.

The activities were assayed using Fraction II under the standard conditions except for the substrate concentration. In (A), the NADP concentrations were 0.5 (一○一), 0.05 (- $\triangle$-), 0.025 (一 $\square$-), 0.0167 (一○-), and $0.0125 \mathrm{~mm}(-\mathbf{\Delta}-)$. ----, secondary plots of the intercept at the vertical line in (B). In (B), the G6P concentrations were $2.0(-\bigcirc-), 0.4(-\triangle-), 0.2$ $(-\square-), 0.13$ (一- - and $0.10 \mathrm{~mm}(-\mathbf{\Delta}-)$. ----, secondary plots of the intercept at the vertical line in (A).

G6P dehydrogenase activity were examined using a modified assay system, in which the concentrations of both substrates were decreased to $0.15 \mathrm{~mm}$, almost the same as the $\mathrm{Km}$ value for G6P. As shown in Table II, the enzyme activity was inhibited specifically by Ru5P and xylulose 5-phosphate among the intermediates of the pentose phosphate pathway, by PRPP, by FBP among the intermediates of glycolysis, by acetyl-CoA, and by oxaloacetate among the intermediates of the tricarboxylic acid cycle. The activity was also inhibited by NADPH, one of the reaction products. NADPH showed the strongest inhibition among the metabolites tested $(52 \%$ at $0.1 \mathrm{~mm}$ ), while oxaloacetate caused $67 \%$ inhibition at $1.0 \mathrm{~mm}$. Whereas analogs of FBP, glucose 1,6-bisphosphate and fructose 2,6bisphosphate, showed slight inhibitory effects, purine nucleotides and aromatic amino acids had no effect on the activity at all.

The inhibition by oxaloacetate, the strongest in Table II except for that by the reaction product, NADPH, was further examined. As shown in Fig. 1, the inhibition by oxaloacetate increased at a lower $\mathrm{pH}$ and was stronger in

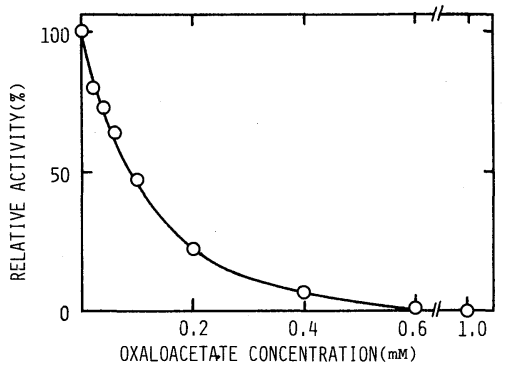

Fig. 3. Effect of Oxaloacetate on the Glucose-6phosphate Dehydrogenase.

The activity was assayed using Fraction II under the standard assay conditions except that TES-NaOH buffer, $\mathrm{pH} 7.0,0.15 \mathrm{~mm}$ G6P, and $0.15 \mathrm{~mm}$ NADP were used. Oxaloacetate was added at the concentrations indicated.

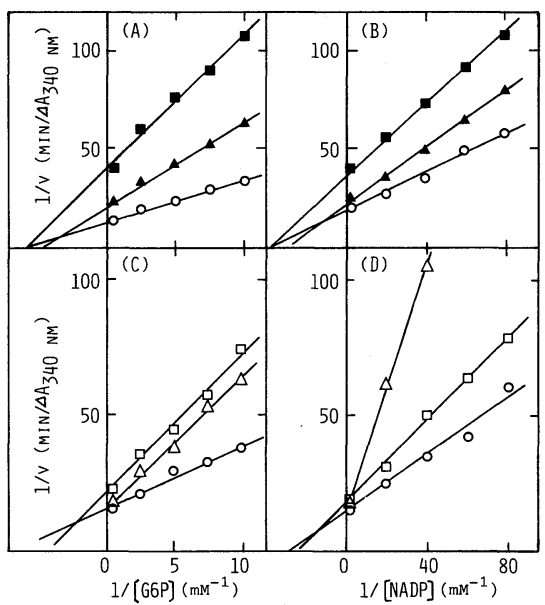

FIG. 4. Double Reciprocal Plots of the Glucose-6phosphate Dehydrogenase Reaction Rate against the Substrate Concentration in the Presence and Absence of Inhibitors.

The activity was assayed using Fraction II under the standard conditions except for the substrate concentration. To the assay mixture, $2 \mathrm{~mm}$ oxaloacetate (- - ), $5 \mathrm{~mm}$ FBP (- - -), $5 \mathrm{~mm}$ PRPP (- $\square-), 0.1 \mathrm{~mm}$ NADPH $(-\triangle-)$, or nothing $(-\bigcirc-)$ was added. The concentration of NADP in (A) and (C) was $0.5 \mathrm{~mm}$ and that of G6P in (B) and (D) was $2.0 \mathrm{~mm}$.

TES-NaOH buffer than in Tris- $\mathrm{HCl}$ buffer, presumably due to the formation of Tris oxaloacetate. Thus, the inhibition by $1 \mathrm{~mm}$ oxaloacetate increased $30 \%$ in TES- $\mathrm{NaOH}$ buffer, $\mathrm{pH} 7.0$, compared with in the case of the assay conditions in Table II. As shown in Fig. 3, oxaloacetate inhibited the activity completely 
at $1.0 \mathrm{~mm}$ in TES-NaOH buffer, $\mathrm{pH} 7.0$. The concentration giving $50 \%$ inhibition was estimated to be $0.09 \mathrm{~mm}$. This suggests the possible operation of the oxaloacetate inhibition under physiological conditions.

Figure 4 shows double reciprocal plots of the reaction rate against the substrate concentrations in the presence and absence of oxaloacetate, FBP, PRPP, or NADPH. They showed the same inhibition types for both the substrates. The inhibition by oxaloacetate, FBP, PRPP, or NADPH was non-competitive, mixed, mixed, or competitive for the substrates, respectively. These results suggest that the former three inhibitors are allosteric inhibitors that bind to different site(s) from the active site, whereas NADPH bound at the active site as the reaction product. The competitive inhibition by the reaction product, NADPH, indicates the reaction mechanism of rapid equilibrium random $\mathrm{BiBi}^{8}$.

The effect of the simultaneous presence of

Table III. Cumulative Inhibition of Glucose- 6PHOSPHATE DEHYDROGENASE

The activity was assayed using Fraction II in the simultaneous presence of two inhibitors under the same conditions as in Fig. 3. The theoretical values for cumulative inhibition are given in parentheses.

\begin{tabular}{lll}
\hline \multicolumn{1}{c}{ Additions } & $\begin{array}{c}\text { Concentration } \\
(\mathrm{mM})\end{array}$ & $\begin{array}{c}\text { Relative } \\
\text { activity } \\
(\%)\end{array}$ \\
\hline None & - & 100 \\
Oxaloacetate & 0.06 & 65 \\
$\quad$ + FBP & $0.06+1.0$ & $34(36)$ \\
+ PRPP & $0.06+1.0$ & $40(42)$ \\
+ Ru5P & $0.06+1.0$ & $41(41)$ \\
+ Acetyl-CoA & $0.06+1.0$ & $66(45)$ \\
FBP & 1.0 & 55 \\
+ PRPP & $1.0+1.0$ & $64(36)$ \\
+ Ru5P & $1.0+1.0$ & $60(35)$ \\
+ Acetyl-CoA & $1.0+1.0$ & $56(38)$ \\
PRPP & 1.0 & 65 \\
+ Ru5P & $1.0+1.0$ & $63(41)$ \\
+ Acetyl-CoA & $1.0+1.0$ & $55(45)$ \\
Ru5P & 1.0 & 63 \\
+ Acetyl-CoA & $1.0+1.0$ & $58(44)$ \\
Acetyl-CoA & 1.0 & 70 \\
\hline
\end{tabular}

inhibitors on the enzyme activity was examined, as shown in Table III. Among five inhibitors tested, the combination of oxaloacetate with FBP, PRPP, or Ru5P caused cumulative inhibition. This suggests that the inhibitions by oxaloacetate and FBP, PRPP or Ru5P operate independently.

\section{Desensitization to the allosteric inhibition}

When the enzyme was precipitated with ammonium sulfate and then removed by dialysis repeatedly three times, the inhibitions by oxaloacetate, FBP, and PRPP were markedly reduced, whereas that by the reaction product, NADPH, as well as the enzyme activity, was not affected by the treatment at all (Table IV). This suggests that the former three inhibitors bind to site(s) different from the active site and labile to the ammonium sulfate treatment. As described previously, the enzyme was also desensitized to the oxaloacetate inhibition on hydroxyapatite chromatography.

\section{Effects of allosteric inhibitors on enzymes from other bacteria}

Since the effects of oxaloacetate, FBP,
Table IV. Effect of Ammonium Sulfate Treat- MENT ON THE SENSITIVITy TO INHIBITION AND THE ACTIVITy OF Glucose-6- PHOSPHATE DEHYDROGENASE

Ammonium sulfate and EDTA were added to Fraction II to 0.7 saturation and $80 \mathrm{~mm}$, respectively. After standing overnight at $5^{\circ} \mathrm{C}$, the enzyme was dialyzed against $0.05 \mathrm{M}$ Tris- $\mathrm{HCl}$ buffer, $\mathrm{pH} 7.5$, containing $0.5 \mathrm{M} \mathrm{KCl}$. This procedure was further repeated twice. Then, the activity was assayed in the presence and absence of each inhibitor under the same conditions as in Fig. 3. The specific activity was determined under the standard assay conditions

\begin{tabular}{lccc}
\hline \multirow{2}{*}{ Inhibitor } & $\begin{array}{c}\text { Concentration } \\
(\mathrm{mm})\end{array}$ & \multicolumn{2}{c}{ Inhibition(\%) } \\
\cline { 3 - 4 } & & Treated & Untreated \\
& & $(212)^{a}$ & $(280)^{a}$ \\
Oxaloacetate & 0.6 & 34 & 96 \\
FBP & 5.0 & 29 & 65 \\
PRPP & 5.0 & 16 & 55 \\
NADPH & 0.06 & 60 & 59 \\
\hline
\end{tabular}

a Specific activity (units/mg protein). 
Table V. Inhibition by Oxaloacetate, Fructose 1,6-Bisphosphate, and Phosphoribosyl Pyrophosphate of Glucose-6-Phosphate Dehydrogenase in Various Bacteria

The bacterial strains were cultured in Medium 7 at $30^{\circ} \mathrm{C}$ for $24 \mathrm{hr}$. The cells were sonically disrupted by the method described in Materials AND METHODS. Supernatant solutions obtained on centrifugation of the sonicates were passed through a Sephadex G-25 column $(1.5 \times 5 \mathrm{~cm})$ equilibrated with $0.05 \mathrm{M}$ Tris- $\mathrm{HCl}$ buffer, $\mathrm{pH} 7.5$, containing $0.5 \mathrm{M} \mathrm{KCl}$, and then used as enzyme preparations. The specific activity was determined under the standard assay conditions and percent inhibition was determined under the same conditions as in Fig. 3 in the presence of $1 \mathrm{~mm}$ oxaloacetate, $5 \mathrm{~mm} \mathrm{FBP}$, or $5 \mathrm{~mm}$ PRPP. The inhibitions in P. putida, B. ammoniagenes and $C$. xerosis were determined with the same substrate concentrations as for the standard assay conditions due to their low enzyme activities.

\begin{tabular}{|c|c|c|c|}
\hline \multirow{2}{*}{ Enzyme source } & \multicolumn{3}{|c|}{ Inhibition $(\%)$} \\
\hline & Oxaloacetate & FBP & PRPP \\
\hline Brevibacterium flavum ATCC 14067 & 94 & 80 & 51 \\
\hline Escherichia coli ATCC 10798 & 3 & 57 & 50 \\
\hline Bacillus subtilis ATCC 6051 & 19 & 47 & 34 \\
\hline Salmonella typhimurium AJ 3224 & 3 & 29 & 34 \\
\hline Pseudomonas putida ATCC 17390 & 2 & 42 & 24 \\
\hline Streptococcus faecalis ATCC 12984 & -1 & 52 & 43 \\
\hline Lactobacillus casei ATCC 7469 & 2 & 51 & 52 \\
\hline Lactobacillus plantarum ATCC 8014 & 4 & 29 & 42 \\
\hline Leuconostoc mesenteroides ATCC 8042 & 1 & 6 & 25 \\
\hline Zymonas mobilis ATCC 29191 & 0 & 18 & 6 \\
\hline Corynebacterium equi ATCC 6939 & -8 & 68 & 48 \\
\hline Corynebacterium xerosis ATCC 373 & 16 & 56 & 2 \\
\hline Corynebacterium glutamicum ATCC 13032 & 89 & 69 & 61 \\
\hline Corynebacterium acetoacidophilum ATCC 13870 & 91 & 69 & 65 \\
\hline Corynebacterium lilium ATCC 15990 & 88 & 70 & 59 \\
\hline Brevibacterium ammoniagenes ATCC 6871 & 8 & 40 & 3 \\
\hline Brevibacterium lactofermentum ATCC 13869 & 89 & 77 & 52 \\
\hline Brevibacterium divaricatum ATCC 14020 & 91 & 63 & 53 \\
\hline Brevibacterium roseum ATCC 13825 & 81 & 68 & 61 \\
\hline
\end{tabular}

and PRPP, found in this study, have not been previously reported for any bacteria, they were examined in 10 genera of bacteria (Table V). The inhibitions by FBP and PRPP were found in almost all bacteria tested as in B. flavum. However, the inhibition by oxaloacetate was found only in glutamate-producing species of the genera, Brevibacterium and Corynebacterium.

\section{Regulation of glucose-6-phosphate dehydro- genase synthesis}

The specific G6P dehydrogenase activities of B. flavum grown on various carbon sources were determined in order to examine regulation of the enzyme synthesis, as shown in Table VI. The activities of cells grown on acetate, glutamate, and succinate, the assimi- lation of which might not require the G6P dehydrogenase reaction, decreased to 4 to $9 \%$ of those of cells grown on glucose. The addition of the same amounts of glucose to these carbon sources increased the specific activity.

\section{DISCUSSION}

The G6P dehydrogenase of B. flavum was found to have similar properties to those of other microorganisms reported. ${ }^{9,10)}$ That is, the enzyme was stabilized by $\mathrm{KCl}$, specific to NADP, required $\mathrm{Mg}^{2+}$, and inhibited by a sulfhydryl reagent. The activity was inhibited by various metabolites such as oxaloacetate, FBP, PRPP, acetyl-CoA, Ru5P, xylulose 5phosphate, and NADPH. Furthermore, the inhibitions by oxaloacetate, FBP, and PRPP 
Table VI. EfFects of Carbon Sources in the Medium on the SPeCific Activity of Glucose-6-Phosphate Dehydrogenase

B. flavum No. 2247 was cultured at $30^{\circ} \mathrm{C}$ for $24 \mathrm{hr}$ with various carbon sources. In Expt. I, Medium 13, of which the concentration of urea was $1.5 \mathrm{~g} /$ liter, was used, and Medium 40 was used in Expt. II and III. When glutamate, succinate, and citrate were used as carbon sources in Expt. II, the strain was cultured for $48 \mathrm{hr}$. The enzyme was prepared by the same method as described in Table V. The specific activity was determined under the standard assay conditions.

\begin{tabular}{|c|c|c|c|}
\hline Expt. & Carbon source & $\begin{array}{c}\text { Growth } \\
\left(A_{562}\right)\end{array}$ & $\begin{array}{c}\text { Specific } \\
\text { activity } \\
\text { (units/mg } \\
\text { protein) }\end{array}$ \\
\hline \multirow[t]{4}{*}{ I } & Glucose & 0.495 & 97 \\
\hline & Fructose & 0.360 & 81 \\
\hline & Ribose & 0.260 & 58 \\
\hline & Gluconate & 0.440 & 87 \\
\hline \multirow[t]{6}{*}{ II } & Glucose & 0.345 & 93 \\
\hline & Lactate & 0.395 & 14 \\
\hline & Acetate & 0.430 & 8.7 \\
\hline & Glutamate & 0.315 & 3.5 \\
\hline & Succinate & 0.190 & 3.9 \\
\hline & Citrate & 0.330 & 40 \\
\hline \multirow[t]{3}{*}{ III } & Acetate + glucose & 0.540 & 74 \\
\hline & Glutamate + glucose & 0.670 & 49 \\
\hline & Succinate + glucose & 0.670 & 27 \\
\hline
\end{tabular}

were not competitive for the substrates. The sensitivities to oxaloacetate, FBP, and PRPP inhibitions were lost on ammonium sulfate treatment, which did not affect the activity, in contrast to that to NADPH inhibition. Oxaloacetate showed cumulative inhibition in combination with FBP, PRPP, or Ru5P. These results indicate that the G6P dehydrogenase of B. flavum is an allosteric enzyme.

Oxaloacetate showed the strongest inhibition among the inhibitors tested and its concentration giving $50 \%$ inhibition was $0.09 \mathrm{~mm}$. Moreover, the inhibition by oxaloacetate was further enhanced by the simultaneous presence of other inhibitors. It is strongly suggested that the inhibition actually operates under physiological conditions in $B$. flavum. These inhibitions of G6P dehydrogenase seem to have the following physiological significance; the inhibition by PRPP is a feedback inhibition of its biosynthesis, that by NADPH is a product inhibition, and those by FBP and oxaloacetate are feedback control of the central carbon metabolism.

Whereas the inhibitions of G6P dehydrogenase by NADPH, ATP, ADP, AMP, inorganic phosphate, acetyl-CoA, and pyridoxal 5-phosphate have been found previously in various microorganisms, ${ }^{9 \sim 13)}$ those by oxaloacetate, FBP, and PRPP found in B. flavum have not been known in any microorganisms. The inhibitions by FBP and PRPP were found in almost all strains tested, suggesting their general operation in bacteria. On the contrary, the inhibition by oxaloacetate was highly specific to glutamate-producing bacteria belonging to the genera, Brevibacterium and Corynebacterium. In Streptococcus faecalis, ${ }^{14)}$ FBP was reported not to inhibit G6P dehydrogenase activity, whereas in this study, it was found to inhibit the activity of a strain of $S$. faecalis, which was not the same strain as in the report. ${ }^{14)}$ This seems to be due to that the reaction system contained lower concentrations of the substrates than in that previous study. ${ }^{14)}$

Compared with glucose as a carbon source, the synthesis of the enzyme was reduced in cultivations with organic acids as carbon sources, which were metabolized through a distant pathway from the G6P dehydrogenase reaction in the metabolic pathway. The addition of glucose to these carbon sources stimulated the synthesis of the enzyme, suggesting the occurrence of the induction by glucose or its metabolite(s). Wolf et al. also showed that the G6P dehydrogenase level decreased in cells grown on acetate as a carbon source in Escherichia coli, but they concluded that the carbon source affected its growth rate, which, in turn, affected the enzyme level. ${ }^{15)}$

Acknowledgments. The authors are indebted to Drs. H. Okada, Y. Komachiya, and R. Tsugawa of the Central Research Laboratories for their encouragement during this work. 


\section{REFERENCES}

1) I. Shiio, S. Otsuka and T. Tsunoda, J. Biochem., 47, 414 (1960).

2) I. Shiio, S. Otsuka and T. Tsunoda, J. Biochem., 46, 1303 (1959).

3) A. Oyama and I. Shiio, Abstracts of Papers, 42nd Annual Meeting of the Japanese Biochemical Society, Hiroshima, October, 1969, p. 535.

4) I. Shiio, S. Sugimoto and K. Kawamura, Agric. Biol. Chem., 48, 2073 (1984).

5) I. Shiio and K. Ujigawa, J. Biochem., 84, 647 (1978).

6) I. Shiio, H. Ozaki and M. Mori, Agric. Biol. Chem., 46, 493 (1982).

7) O. H. Lowry, N. J. Rosebrough, A. L. Farr and R. J. Randall, J. Biol. Chem., 193, 265 (1951).

8) W. W. Cleland, Biochim. Biophys. Acta, 67, 104 (1963)
9) E. A. Noltmann and S. A. Kuby, "The Enzymes," Vol. 7, ed. by P. D. Boyer, H. Lardy and K. Myrback, Academic Press Inc., New York, 1963, p. 223.

10) G. F. Dmagk and R. Chilla, "Methods in Enzymology," Vol. 41, ed. by W. A. Wood, Academic Press Inc., New York, 1975, p. 205.

11) R. N. Horne, W. B. Anderson and R. C. Nordlie, Biochemistry, 9, 610 (1970).

12) T. Lessie and F. C. Neidhardt, J. Bacteriol., 93, 1337 (1967).

13) C. Olive and H. R. Levyl, "Methods in Enzymology," Vol. 41, ed. by W. A. Wood, Academic Press Inc., New York, 1975, p. 196.

14) A. T. Brown and C. L. Wittenberger, J. Bacteriol., 106, 456 (1971).

15) R. E. Wolf, Jr., D. M. Prather and F. M. Shea, J. Bacteriol., 139, 1093 (1979). 